\title{
Reminiscences of Days as an Undergraduate at Caltech in the 1960s: Geology, Student Body Politics and Intercollegiate Football
}

\author{
Robert Cooper Liebermann \\ Mineral Physics Institute and Department of Geosciences, Stony Brook University, Stony Brook, NY, USA \\ Email: Robert.Liebermann@stonybrook.edu
}

How to cite this paper: Liebermann, R. C. (2021) Reminiscences of Days as an Undergraduate at Caltech in the 1960s: Geology, Student Body Politics and Intercollegiate Football. International Journal of Geosciences, 12, 653-666.

https://doi.org/10.4236/ijg.2021.128037

Received: June 28, 2021

Accepted: August 3, 2021

Published: August 6, 2021

Copyright $\odot 2021$ by author(s) and Scientific Research Publishing Inc. This work is licensed under the Creative Commons Attribution International License (CC BY 4.0).

http://creativecommons.org/licenses/by/4.0/

\begin{abstract}
From 1960 to 1964, I was an undergraduate student at the California Institute of Technology [Caltech] in Pasadena, California. During these years, I spent much of my time indulging in student body politics and playing intercollegiate football. However, with the encouragement of a number of faculty in the Division of Geological Sciences [not yet GPS], I saw the light and became a geology major [strictly speaking, geophysics]. This paper is an expansion of a talk I presented at the $90^{\text {th }}$ Anniversary of the Division of Geological and Planetary Sciences in 2017.
\end{abstract}

\section{Keywords}

Undergraduate, Geology, Student Body Politics, Intercollegiate Football

\section{Introduction}

Over the past decade, I have concentrated on writing papers on my history pursuing a scientific career in mineral physics. The first 3 of these papers appeared in a Special Issue of the journal Minerals and were later included in the book volume on "Mineral Physics: In Memory of Orson Anderson": these included "The Orson Anderson era of mineral physics at Lamont in the 1960s" [1]; "The birth of mineral physics at the ANU in the 1970s" [2]; "My career as a mineral physicist at Stony Brook: 1976-2019" [3]; and "Bob-san and high pressure science and technology in Japan: A 40-year history" [4]. More recently, I have also published a papers on "Stony Brook's high-pressure laboratory collaborations with French scientists" and "Stony Brook's Collaborations with Czech Scientists" in the International Journal of Geosciences [5] [6]. This new paper is of a similar genre.

In spring 1960, I was offered admission to the California Institute of Technology 
[Caltech] and decided to accept. My decision was influenced by cousin Robert Cooper who had attended Caltech in late 1930s.

\section{Geology}

I enrolled at Caltech in September 1960, intending to major in math. However, Richard McGehee, my freshman roommate in Ruddock House was a REAL math major, and so I sought refuge in electrical engineering [knowing that I was not strong enough to be a major in physics; although in a sophomore physics lab, I used a Foucault pendulum to demonstrate the Earth's rotation].

However, in the $1^{\text {st }}$ term of my sophomore year, I took the GE 1 class taught by Professor Bob Sharp, which convinced many of us to major in geology. Doc Sharp served as my informal advisor throughout my years at Caltech and we later exchanged Christmas cards each year until his death. (Figure 1)

During my years as a geology major, I was fortunate to be tutored by many outstanding faculty in the Division. (Figure 2)

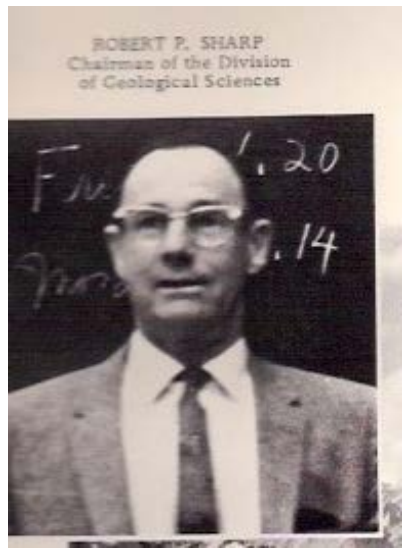

Figure 1. Professor Robert Sharp, chair of division of geological sciences.

\section{Major: Math $>>>E E>>>$ Geology}

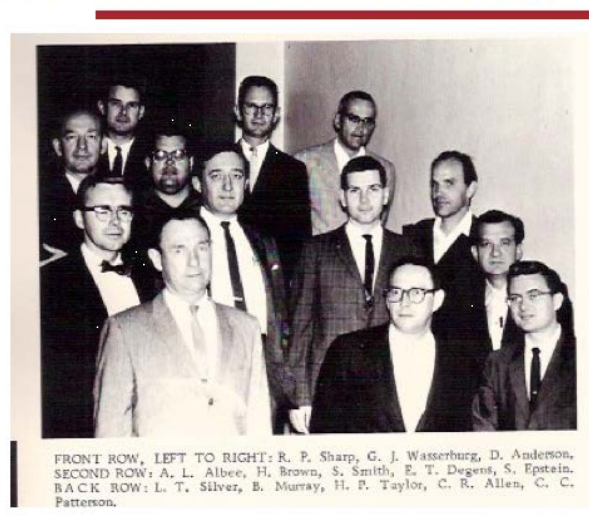

Geology faculty in 1963-64

Figure 2. Geology faculty at Caltech in 1963-64. 
GEO faculty and courses taught: Silver and Wasserburg-mineralogy; Albee and Degens-petrology; Allen and Taylor-field geology; Brown and Lowenstam-paleogeology; Anderson-interior of Earth; Press-geophysics—when Press was in Geneva negotiating an underground nuclear testing treaty, Leon Knopoff from UCLA substituted for him.

Stewart Smith—academic advisor.

Prof. Gerry Wasserburg never forgave Dave Hewitt and me for skipping mineralogy lab every Wednesday, so that we could play our intercollegiate baseball games.

\section{Field trips to Rainbow Basin and Panamint Valley}

In the winter and spring terms of our junior year, Clarence Allen, Hugh Taylor and Robert Phinney led field trips to special geological sites in southern California. Among the fellow students on these field trips were Tony Dahlen, Dave Hewitt and Leon Thomsen - all of whom were also on the football team.

Professor Allen always brought beer for us undergrads who were all underage 21. (Figure 3 \& Figure 4 )

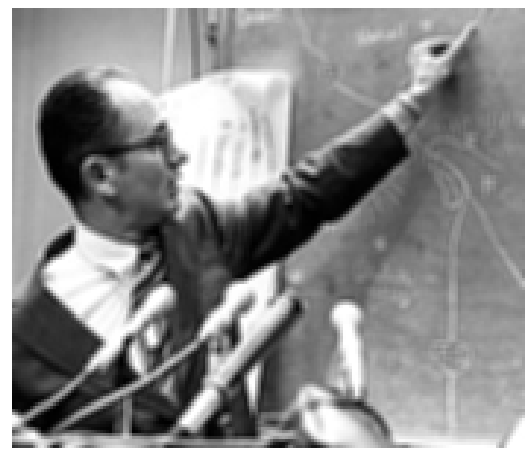

Figure 3. This photo of Allen is from a lecture he gave after returning from investigating the field consequences of the Great Alaskan Earthquake in April 1964. His studies revealed important insights into the mechanism of this earthquake and led to important modifications to the newly-developing theory of plate tectonics.

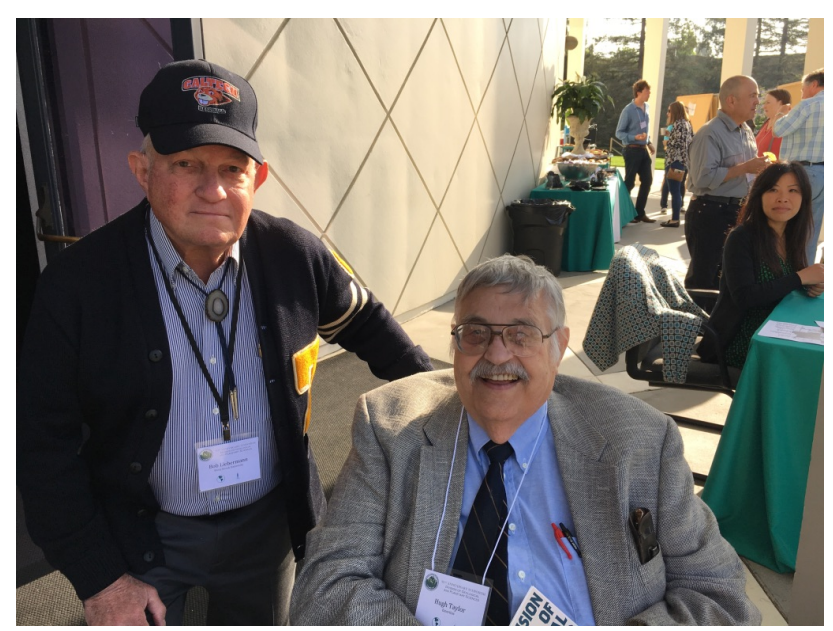

Figure 4. Bob and Hugh Taylor [BS 1954] at the Division $90^{\text {th }}$ celebration in 2017; Hugh also played football as an undergrad. 
Rainbow Basin field trips (Figure 5)

Hugh Taylor would climb to rim of Rainbow Basin and suggest that he could map the basin from there. (Figures 6-8)

Panamint Valley field trips (Figures 9-11)

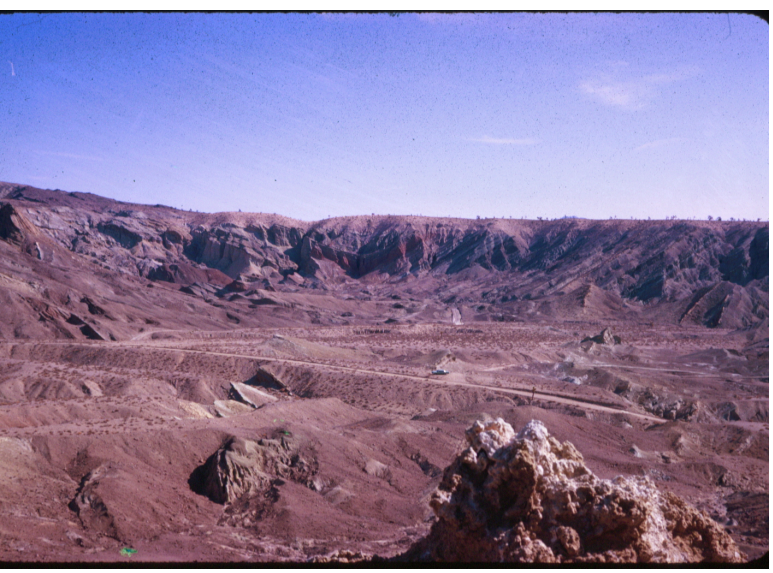

Figure 5. Rainbow Basin, S. Calif-it's not Barringer Crater, but nonetheless very impressive.

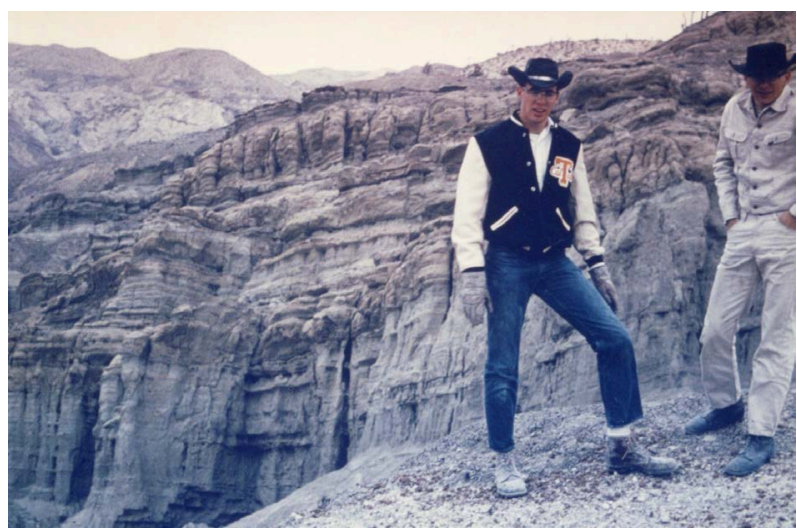

Figure 6. Split end Leon Thomsen on outcrop in Rainbow Basin 1963.

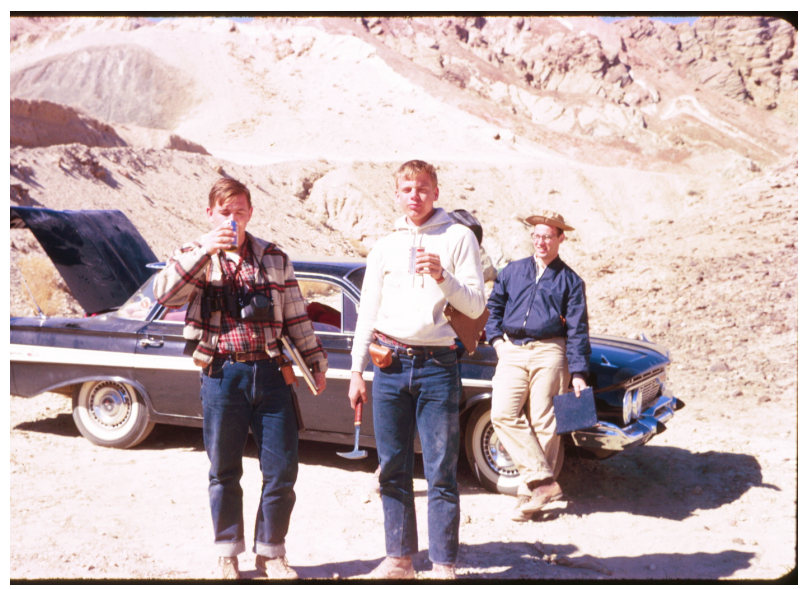

Figure 7. Linemen Dave Hewitt and Tony Dahlen preparing for mapping in Rainbow Basin 1964. 


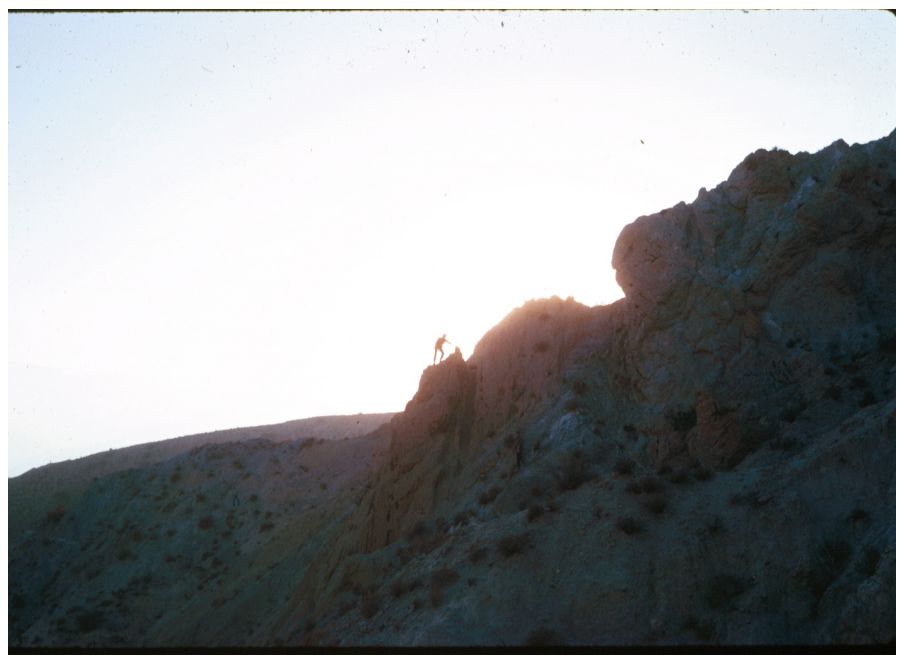

Figure 8. Tony Dahlen reaching for the stars-at crest of Rainbow Basin.

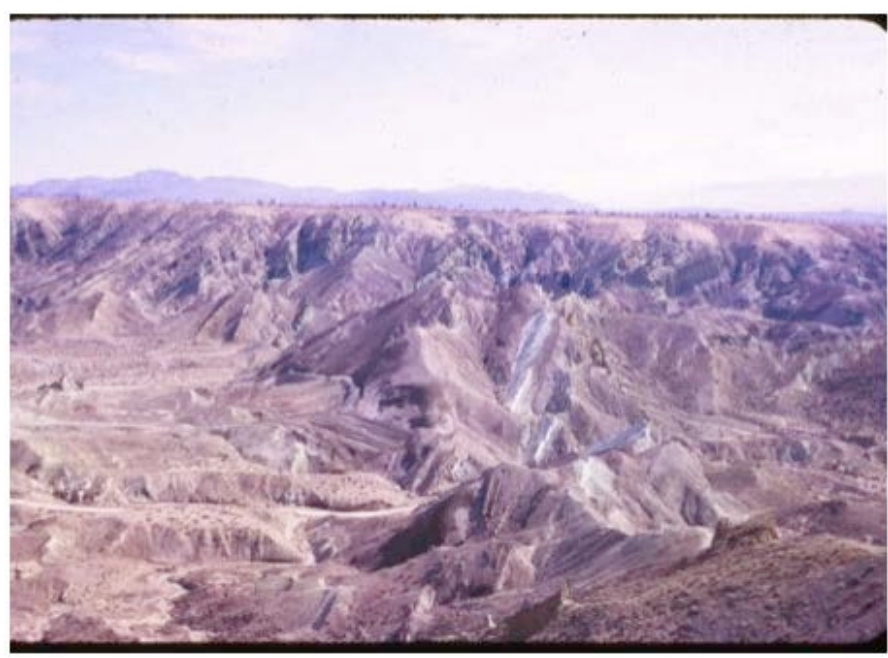

Figure 9. Panamint Valley, California.

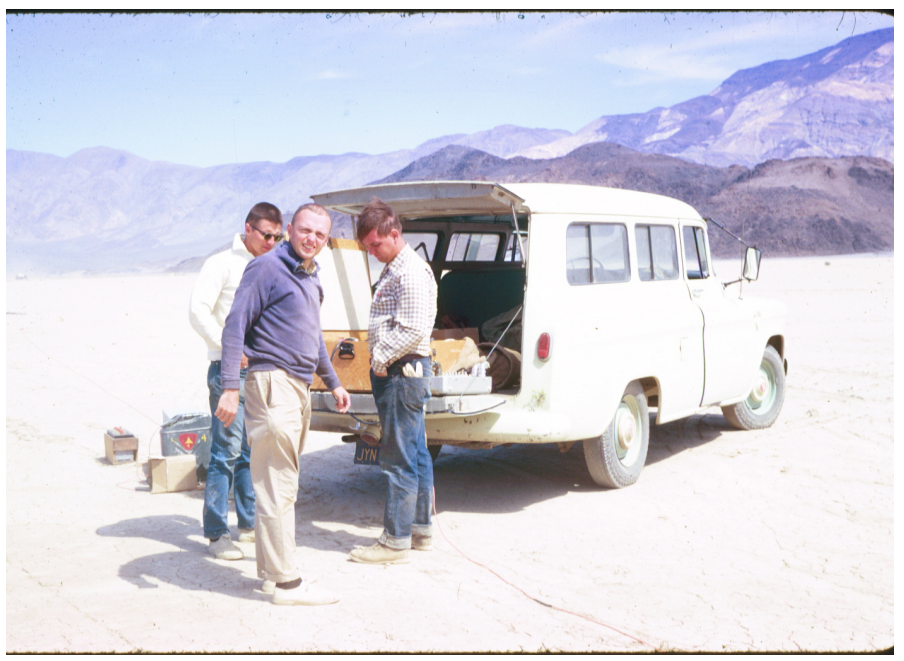

Figure 10. "Noted geologist" Bob Phinney leading field trip to Panamint Valley-1963, where we conducted refraction seismic and geodetic surveys. 


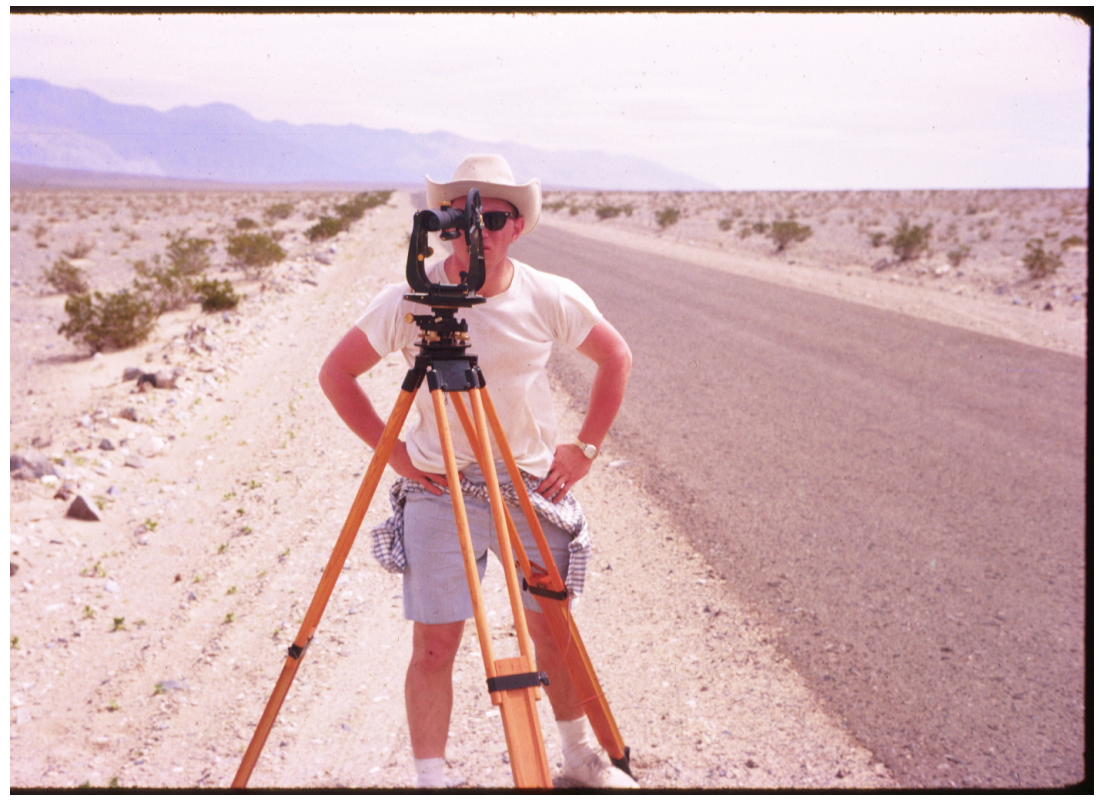

Figure 11. Bob during brief sojourn as outdoor geophysicist-Panamint Valley.

In addition to our field work in Rainbow Basin and Panamint Valley, we visited sites of earthquake damage in southern California, including the San Andreas and Garlock faults. It was 1906 earthquake which caused the dramatic strike-slip displacement of the San Andreas fault.

On a more mundane level, one of the geology faculty hired me to sort and pack up the rock collection of former Caltech faculty member, Richard Jahns, who had recently left Caltech for Stanford University. This task was performed in the sub-basement of the Arms Laboratory during many nights of my senior year, but it did provide money for me to fly my girlfriend Barbara to Pasadena to celebrate Lost Weekend in spring 1964.

\section{Student Body Politics}

Outside of the classroom and field trips, much of my time was spent dabbling in student body politics. (Figure 12)

ASCIT period: Associated Students of California Institute of Technology

In 1962-63, I served as the ASCIT Athletic Manager, during which time I campaigned for an increase in student activity dues in support of athletic programs. I also supported the proposal of my freshman roommate Richard McGehee to establish a Wrestling team; by the 1963 season, the team won the SCIAC championship and McGehee posted the best won-lost record.

In spring 1963, I was elected ASCIT President and Chair of the Board of Directors (Figure 13).

On November 22, 1963, we learned that President John Kennedy had been assassinated in Dallas, Texas. Later that day, I went to President DuBridge's house to ask him to instruct Professor Thomas Apostol to cancel the weekly Monday math quiz. President DuBridge was out of town, but Mrs. DuBridge invited me 


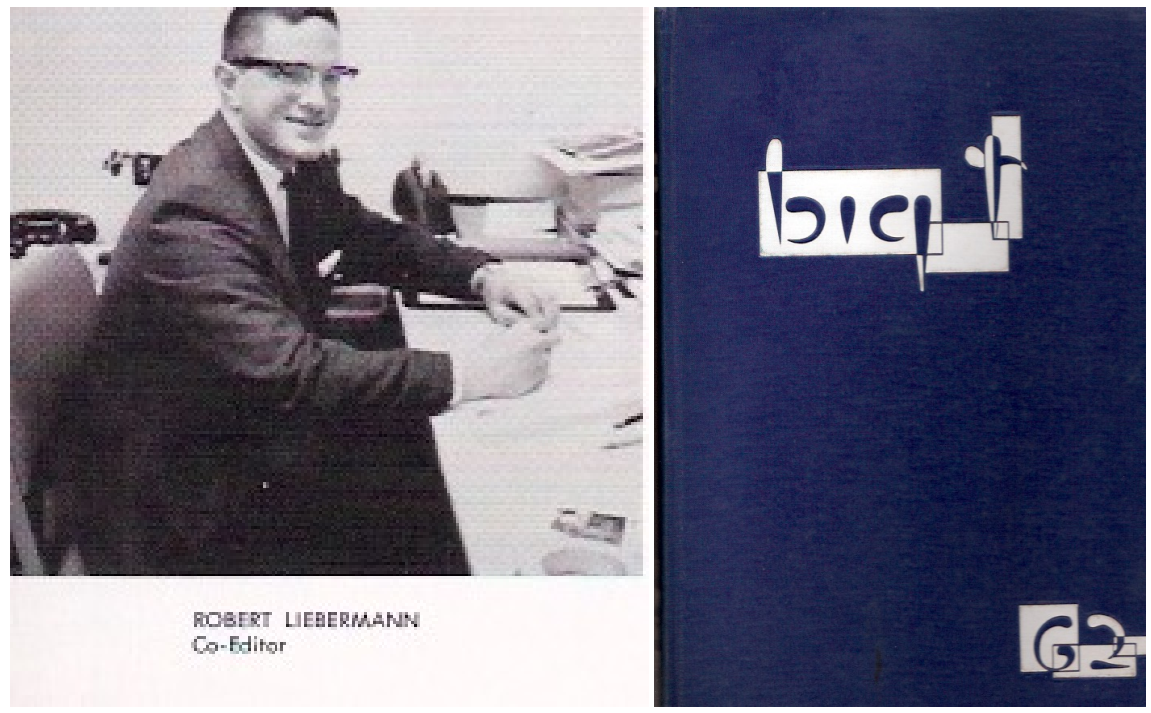

Figure 12. In 1961-62, I was the athletic manager of Ruddock house and co-editor of the big T yearbook [moving up from Sports Editor of the 1960-61 yearbook].

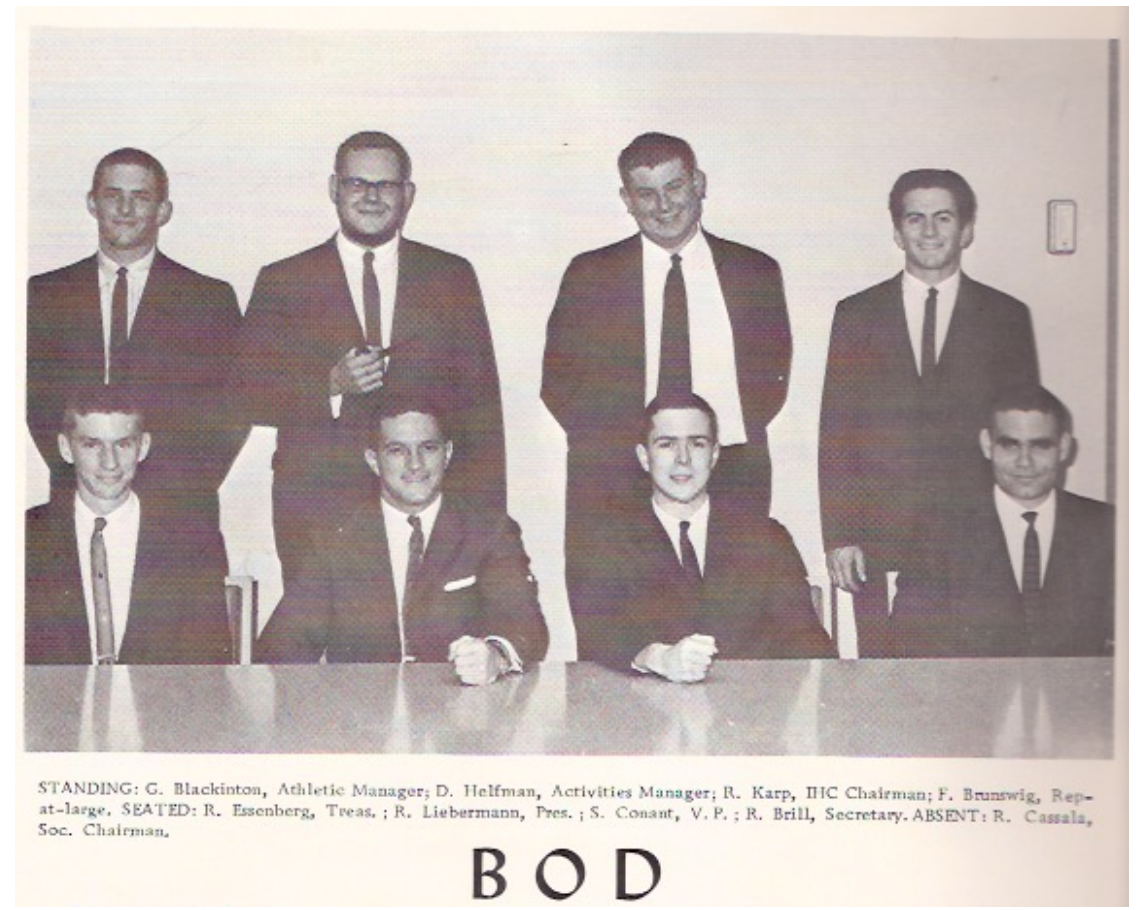

Figure 13. In spring 1963, I was elected ASCIT president and chair of the board of directors [BOD].

to dinner [as she felt lonely]; regrettably, I declined so that I could transmit the quiz cancellation news to all residential houses. Our final football game of the 1963 season was postponed to November 27. On behalf of the Caltech student body, I sent condolences to Jacqueline Kennedy and received a personal acknowledgement from her [which I still have].

As ASCIT President, I had the honor of introducing Robert F. Kennedy (Figure 14). RFK thought he was invited to give the commencement address, but that 


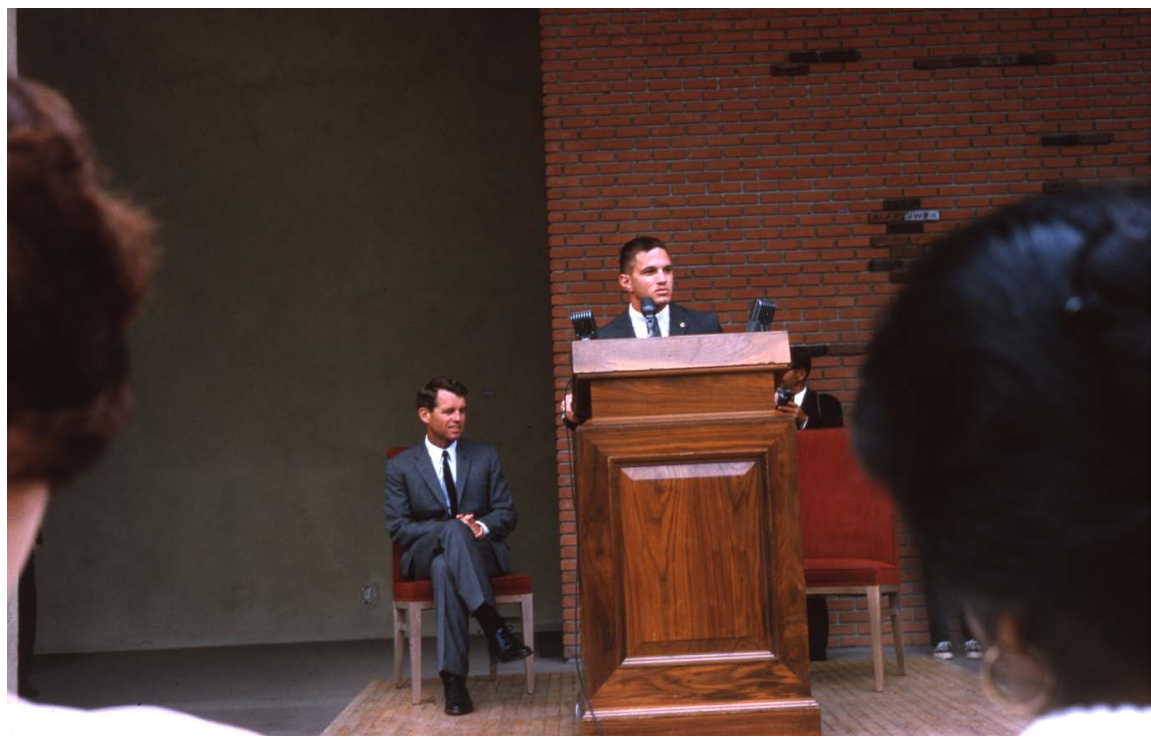

Figure 14. ASCIT President Bob Liebermann introducing Robert F. Kennedy at Caltech May 1964 in front of the new Winnett Student Center.

honor was reserved for a wealthy donor.

At the 1964 commencement ceremony, President DuBridge presented me with the Frederic W. Hinrichs Jr., Memorial Award. This award is given annually to the senior or seniors who have made the greatest contributions to the student body and whose qualities of character, leadership, and responsibility have been outstanding (Figure 15).

\section{Intercollegiate Football}

In the summer 1960, I wrote a letter to Athletic Director Hal Musselman asking if I could try out for the football team and offered to send game films from Patchogue High School's 1959 season in which I played defensive end and quarterback. Director Musselman replied by letter and wrote: "Just show up!"

The faculty of the Division of Geological Sciences [not yet GPS] were strong supporters of our football teams. Bob Sharp, Division Chair, often watched our practices on campus field while jogging around the track [Sharp was the quarterback and captain of the 1933 team]. Hugh Taylor and Clarence Allen also often attended our games.

I lettered for 4 seasons in football, playing mostly quarterback and occasionally halfback.

Our best season was in 1963, when we won two games and should have one two more; in the LaVerne game, we were ahead in the fourth quarter when I threw an interception which was returned for a touchdown. That was not my only interception, but the only one for a "pick six." At a training table lunch one day, Chuck Vinsonhaler invoked that tendency by asking me to "hand off the salt, please".

Four of the starters on the 1963 team later became geology faculty at major U. S. universities: (Figure 16): Guard Tony Dahlen: Princeton \#63, Tackle Dave Hewitt: Virginia Tech \#52, Split end Leon Thomsen: SUNY at Binghamton \#88 and 


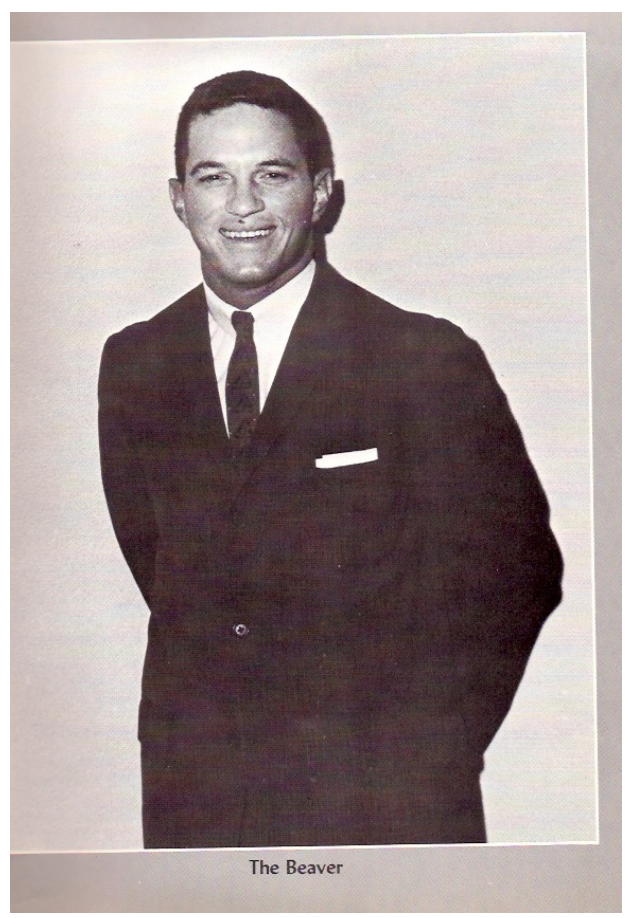

Figure 15. The Beaver: my nickname acquired from compulsion for intercollegiate athletics and student body politics.

Quarterback Bob Liebermann: Stony Brook University \#11. Rick O’Connell was also on the 1963 team, but not in the team photo; he later was on the geology faculty of Harvard University.

Although not a geologist, Mike Rosbash [\#72] was a tackle on both the 1962 and 1963 teams. Now on the faculty of Brandeis University, in 2017 he was the co-winner of the Nobel Prize in Physiology or Medicine.

After we defeated L.A. Pacific, the students lit a bonfire on San Pasqual Blvd. When we beat Riverside the next seek, the students used old telephone poles to light a large conflagration on California Blvd. On the following Monday, Dean of Students Paul Eaton called me into his office, where I met with the Fire Chief of Pasadena in my capacity as ASCIT President [ASCIT-Associated Students of California Institute of Technology]. The Chief asked me what I was going to do to assure him that there would be no more bonfires. In my role as quarterback of the football team, I told him that I could guarantee that: "We will not win any more games".

Our home games were played in the Rose Bowl (Figure 17). Later in my career at Stony Brook University, Dan Davis [our department chair at Stony Brook] often introduced me as the person who had quarterbacked most games in the Rose Bowl [obviously, not in the Rose Bowl games on New Year's Day].

We played Occidental College on their field in 1963 [see Guard Ton Dahlen (63) protecting QB Liebermann (11) in Figure 18]. Note large crowd in stands. At memorial for Tony Dahlen at Princeton, I showed this photo and Robert Phinney remarked: “That was Tony: Always had his eye on the ball." I replied: 


\section{Varsity...}

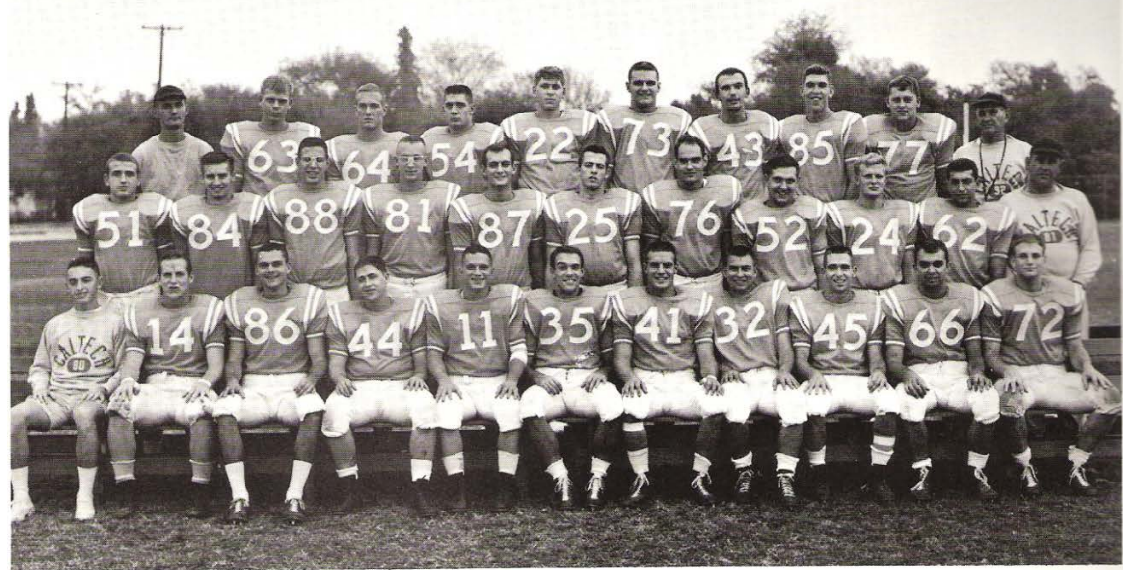

FRONT ROW: Mike Cosgrove (Manager), Bob Christie, Steve Hall, Guy Jackson, Bob Liebermann, Jon Evans, Barry Dinius, Don Green, Bob Scott, Joe Taynai, Mike Roshbash. MIDDLE ROW: Chuck Vinsonhaler, Art Johnson, Leon Thomson, Roger Card, Lee Peterson, Tom DeKlyen, Dave Hewitt, Marty Westbrook, Bill Rosenberg, Coach Calhoun. BACK ROW: Coach Van Kirk, Tony Dahlen, Dave Stolfa, Lee Myers, Murray Sherman, Jud Palmer, Val Ellis, Doug Josephson, Andy Kampe, Coach LaBrucherie. NOT SHOWN: Mike Costello, Gordon Myers, Dave Posner, Bob Serafin.

This was the football squad's first multi-win season in recent history. We won 2, beating LA Pacific and UC Riverside, and scared 2, losing to Cal Lutheran and La Verne in the last few minutes of play after leading in both games thru the 3rdquarter. Injuries prevented Tech from having a truly amazing season. With Liebermann at quarterback, and Evans and Dinius in the backfield, we had a potent ground offense that brought scores in all games but one.

\section{VARSITY RECORD}

\section{CalTech 32 L.A. Pacific}

CalTech 14 UC Riverside

CalTech 6 LaVerne

CalTech 6 Santa Clara

CalTech 14 Cal Lutheran

CalTech 8 Occidental

CalTech 0 Claremont-Mudd

Figure 16. Caltech football team in 1963.

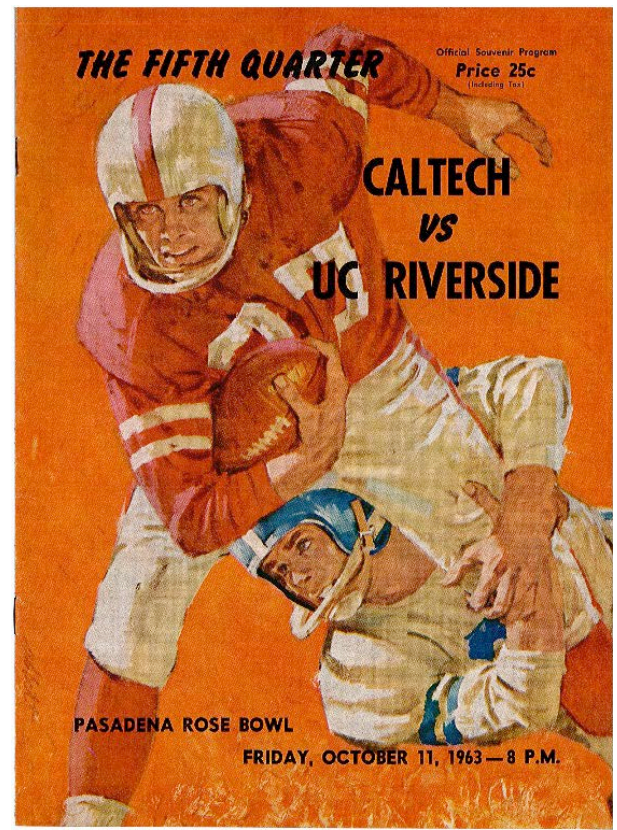

Figure 17. Program for football game in Rose Bowl on Oct. 11, 1963. 


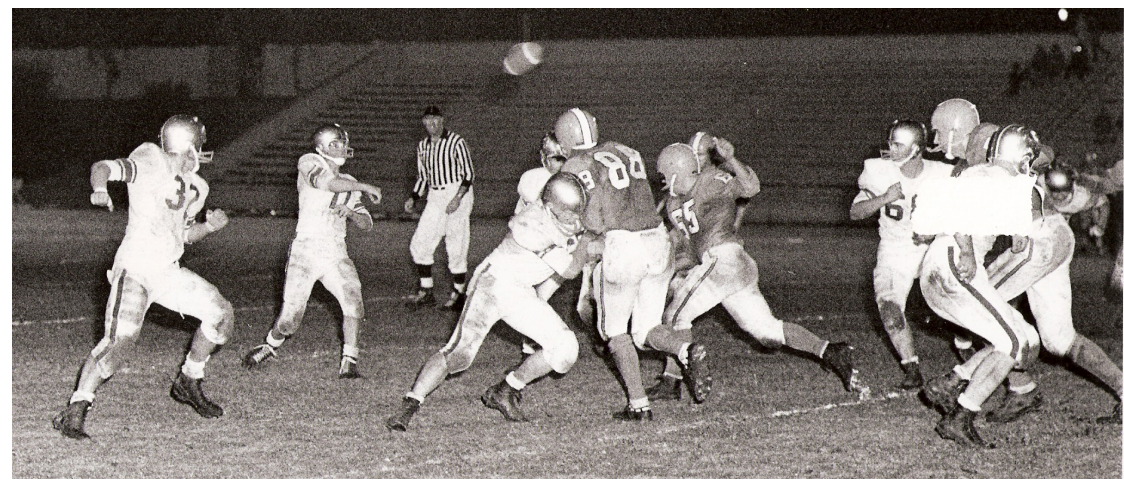

Figure 18. Football game of Caltech vs. Occidental College in 1963.

"Yes, but I would have preferred that he was focusing on blocking."

Two Robert Coopers have played quarterback for Caltech (Figure 19).

1938: Robert George Cooper [my cousin and namesake],

1963: Robert Cooper Liebermann.

My uncle George Cooper was the basketball coach at Caltech in the 1930s; his family lived in Pasadena on San Pasqual Blvd and my cousin was on the basketball and football teams.

The undergrads at Caltech living in Lloyd House in the 1960s were widely known as wild jokers. At the Rose Bowl game on New Year's Day in 1961, they engineered a spoof on the Washington Huskies football team, replacing Washington with Caltech in one of the halftime card displays (Figure 20). Another display replaced the image of Huskies with one of Beavers.

\section{Transition from Caltech to Columbia in 1964}

As an undergraduate at Caltech, I spent much of my time playing intercollegiate football and indulging in student body politics. However, in my senior year, I was fortunate to take a seminar reading course in geophysics from Don Anderson, who introduced me to studies of the deep interior of the Earth.

\section{Don Anderson introduced Bob to deep Earth geophysics (Figure 21)}

When I applied for graduate school at Columbia University, my candidacy was in the discard pile due to a 2.7 cumulative GPa, until Stewart Smith of Caltech called George Sutton at the Lamont Geological Observatory and convinced him to resurrect my application. Sutton had been impressed by the performance of Art McGarr, who preceded me to Columbia, and not only sponsored my admission but offered me a summer job working with Gary Latham on the adaption of a lunar [never deployed] seismometer to the ocean bottom.

While Stewart Smith was lobbying Columbia on my behalf, Gerry Wasserburg was offering me some sage advice:

He told me that I was crazy to make the two biggest decisions of my life in the same year:

Marrying your high school sweetheart [still happily married in 2021] and Commencing graduate study. 

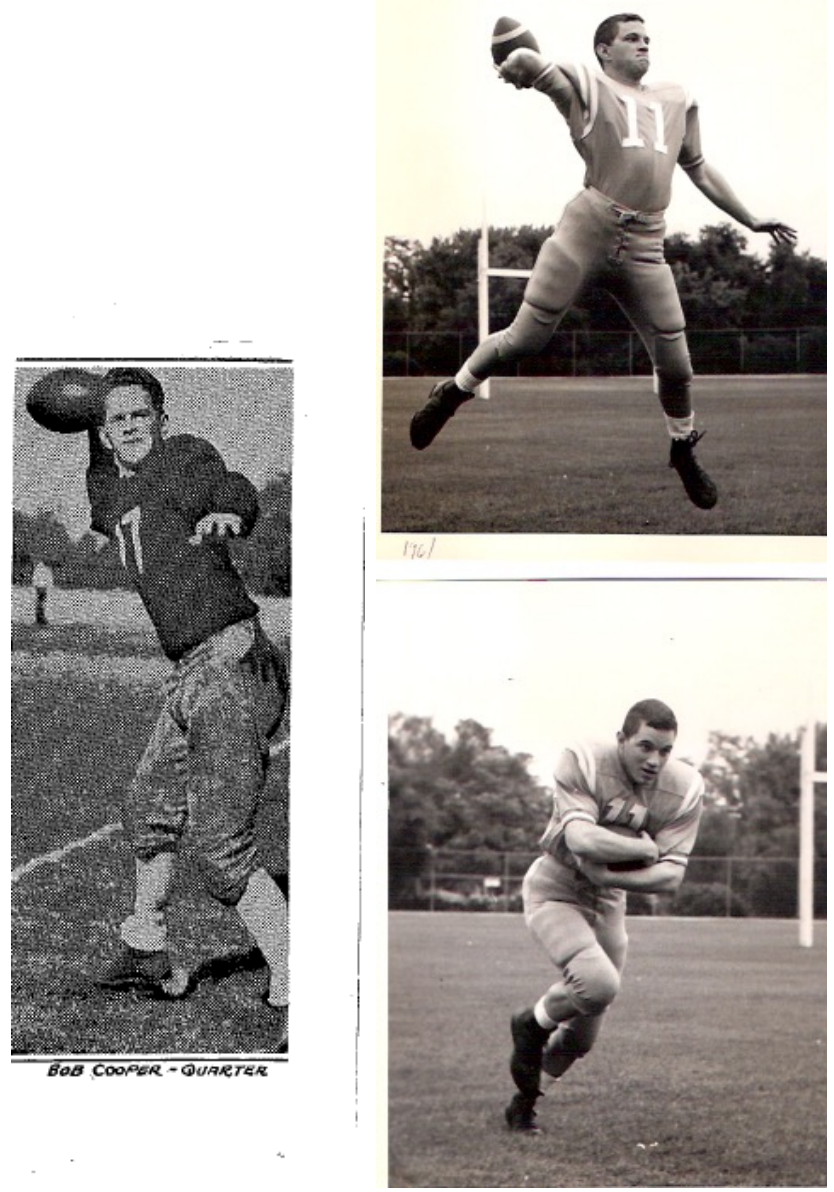

Figure 19. Cooper quarterbacks at Caltech. 1938: Robert George Cooper. 1963: Robert Cooper Liebermann.

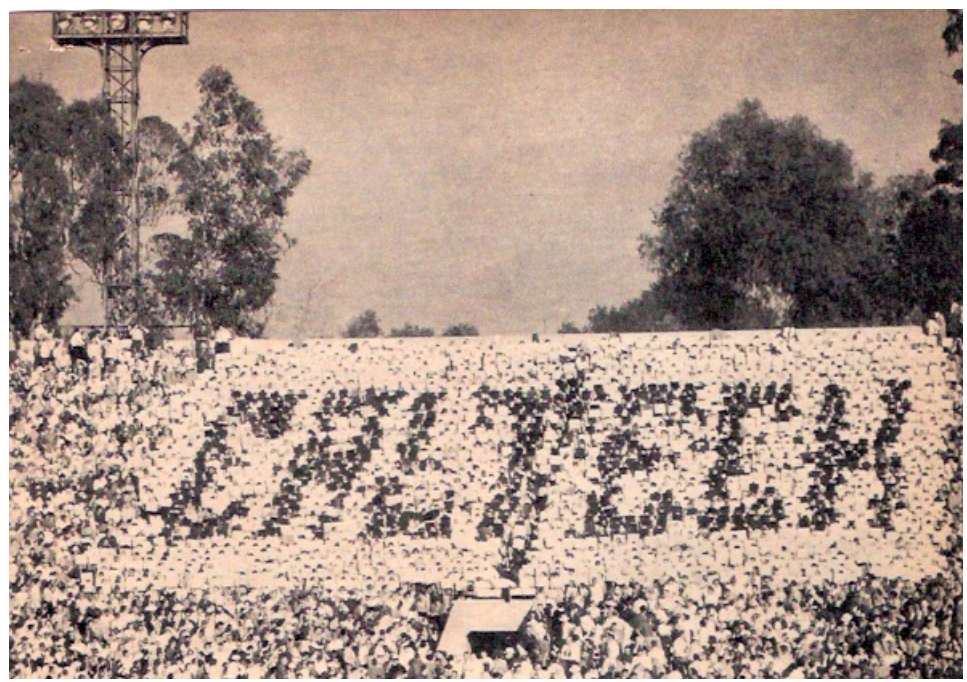

Figure 20. The undergrads at Caltech living in Lloyd House in the 1960s were widely known as wild jokers. At the Rose Bowl game on New Year's Day in 1961, they engineered a spoof on the Washington Huskies football team, replacing Washington with Caltech in one of the halftime card displays. Another display replaced the image of Huskies with one of Beavers. 


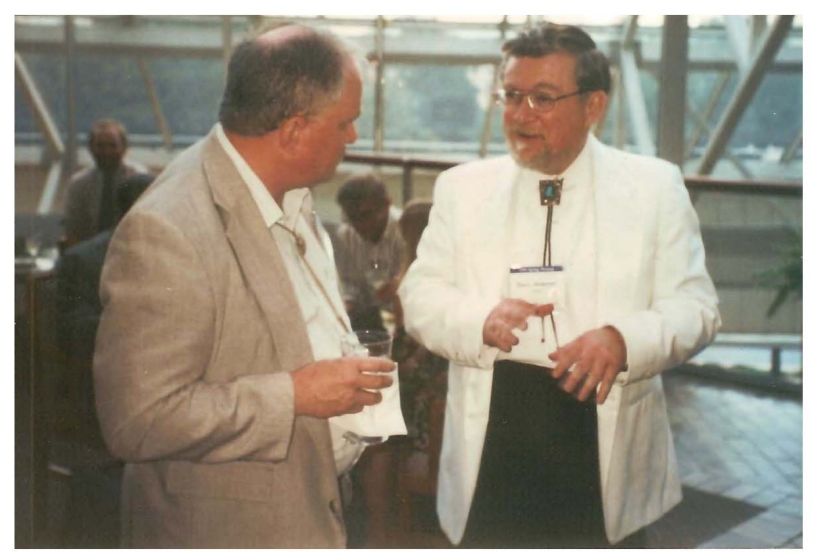

Figure 21. Bob with Don Anderson at AGU Honors Ceremony.

As it turned out, Gerry was proved wrong, as my wife Barbara [Phi Beta Kappa from Elmira College] taught me how to be a serious student again.

\section{Conclusions}

I spent six years from 1964 to 1970 as a graduate student at Columbia working in the mineral physics laboratory of Orson Anderson at the Lamont Geological Observatory, and then departed for Australia with our family of three and worked for six years to establish a mineral physics laboratory in the Research School of Earth Sciences of the Australian National University in Canberra.

In 1976, our expanded family of five [including two Aussies] moved back to the U.S. to Long Island, New York, where I was a faculty member of the Department of Geosciences at Stony Brook University for the next 38 years. In 2014, I formally retired and am now a Research Professor. I spend my days informally advising graduate students of my colleagues in mineral physics and writing papers on the history of science; attached are references to several of these recent endeavors.

The first 3 of these papers were later published in a book volume of this Special Issue entitled:

Mineral Physics-In Memory of Orson Anderson, R. C. Liebermann Guest Editor, Print edition of Special Issue of MINERALS, 628 pp., mdpi, 2020.

\section{Acknowledgements}

I am grateful to my undergraduate colleagues Dave Hewitt and Leon Thomsen contributing photos and correcting my memories of our days together at Caltech.

\section{Conflicts of Interest}

The author declares no conflicts of interest regarding the publication of this paper.

\section{References}

[1] Liebermann, R.C. (2019) The Orson Anderson Era of Mineral Physics at Lamont in the 1960s. Minerals, 9, 342-360. https://doi.org/10.3390/min9060342 
[2] Liebermann, R.C. (2020) The Birth of Mineral Physics at the ANU in the 1970s. Minerals, 10, 163. https://doi.org/10.3390/min10020163

[3] Liebermann, R.C. (2019) My Career as a Mineral Physicist at Stony Brook: 1976-2019. Minerals, 9, 761. https://doi.org/10.3390/min9120761

[4] Liebermann, R.C. (2011) Bob-san and High Pressure Science Technology in Japan: A 40+-Year History. The Review of High Pressure Science and Technology, 21, 115-126. https://doi.org/10.4131/jshpreview.21.115

[5] Liebermann, R.C. (2021) Stony Brook’s High-Pressure Laboratory Collaborations with French Scientists. International Journal of Geosciences, 12, 195-212. https://doi.org/10.4236/ijg.2021.123012

[6] Liebermann, R.C. (2021) Stony Brook's Collaborations with Czech Scientists. International Journal of Geosciences, 12, 487-498.

https://doi.org/10.4236/ijg.2021.125026 